\title{
AKTIVITAS EKSTRAK ETANOL DAUN PEPOLO (Bischofia javanica BLUME) TERHADAP PENYEMBUHAN LUKA BAKAR PADA KELINCI (Oryctolagus cuniculus)
}

\section{(ACTIVITY OF ETHANOL EXTRACT OF PEPOLO (Bischofia javanica BLUME) LEAVES IN BURN TREATMENT ON RABBITS (Oryctolagus cuniculus))}

\author{
SUHAENI $^{\bullet}$, YUSRIADI $^{1}$, AKHMAD KHUMAIDI $^{1}$ \\ ${ }^{1}$ Jurusan Farmasi, FMIPA Universitas Tadulako, Palu - Sulawesi Tengah, 94118
}

\begin{abstract}
Abstrak: Tumbuhan daun pepolo (Bischofia javanica Blume) merupakan salah satu tumbuhan yang digunakan untuk pengobatan luka bakar. Penelitian ini bertujuan untuk mengetahui aktivitas ekstrak daun pepolo terhadap penyembuhan luka bakar pada kelinci (Oryctolagus cuniculus). Pengujian aktivitas ekstrak etanol daun pepolo menggunakan 5 ekor kelinci yang dibagi dalam 5 kelompok perlakuan yaitu kontrol negatif (basis gel tanpa ekstrak), ekstrak etanol daun pepolo dalam basis gel dengan konsentrasi 5\%, 10\%, 15\% dan kontrol positif (gel Bioplacenton). Pengukuran diameter luka dilakukan pada hari ke- 1, 3, 5, 7, 9, 11, 13, 15, 17, 19, dan 21. Data yang diperoleh dianalisis secara statistik dengan Metode One Way Anova. Hasil analisis statistik menunjukkan bahwa ekstrak daun pepolo pada konsentrasi 5\%, 10\% dan 15\% memiliki aktivitas penyembuhan luka bakar. Penyembuhan luka bakar yang efektif yaitu konsentrasi 15\%, yang memberikan penyembuhan sebesar $92,34 \%$.
\end{abstract}

Kata kunci: Bischofia javanica Blume, daun pepolo, ekstrak etanol, luka bakar, kelinci.

Abstract: Pepolo (Bischofia javanica Blume) is one of numerous plants used in treating burn. This study aims to determine the activity of the bishop wood leaves extract in burn treatment on rabbits (Oryctolagus cuniculus). In testing the activity of the ethanol extract of pepolo leaves 5 rabbits was employed and divided into 5 treatment groups, namely negative control (gel-based without extract), ethanol extract of pepolo leaves on a gel base with a concentration of 5\%,10\%,15\% and positive control (Bioplacenton gel). The identification regarding the wound diameter was conducted on day $1,3,5,7,9,11,13,15,17,19$, and 21 . The data obtained were statistically analyzed using the One Way Anova method. The result of the statistical analysis shows that the healing treatment activity is present on the administration of the extract of pepolo leaves. The effective healing of burns is concentration of $15 \%$, which provides a cure of $92,34 \%$.

Keywords: Bischofia javanica Blume, burn, ethanol extract, Pepolo, rabbit.

\section{PENDAHULUAN}

Luka bakar menjadi masalah kesehatan masyarakat di seluruh dunia (Gupta et al.,2016). Menurut Peck Michael, Joseph Molnar \& Dehran Swart dalam Bulletin of the World Healt Organization A global plan for burn prevention and care (2009), bahwa setiap tahun lebih dari 300.000 orang meninggal akibat luka bakar, jutaan lebih menderita cacat tubuh yang mempengaruhi efek pada psikologis, sosial dan ekonomi. Hal ini membuat luka bakar menjadi salah satu penyebab cedera utama. Berdasarkan data Riset Kesehatan Dasar (2013), prevalensi luka bakar di Indonesia sebesar $0,7 \%$ dan prevalensi tinggi pada usia 1- 4 tahun sebesar $1,5 \%$. Sekitar $73 \%$ kasus kematian dalam lima hari pertama setelah terbakar disebabkan oleh komplikasi infeksi. Meskipun tatalaksana pada luka bakar sudah berkembang pesat, namun risiko terjadi infeksi melalui kulit yang luka atau terbuka masih tinggi (Ekrami and Kalantar, 2007).

Luka bakar dapat diatasi dengan cara perawatan kompleks yaitu mengurangi nyeri pada tubuh, memerlukan perawatan di rumah sakit yang lama dengan berbagai macam prosedur operasi dan waktu rehabilitasi yang lama (Khorasani, 2009). Penderita luka bakar memerlukan pengobatan langsung untuk mengembalikan fungsi kulit normal hal ini membuat perawatan luka bakar mengeluarkan biaya yang mahal sehingga dibutuhkan obat tradisional sebagai terapi alternatif dan biaya yang terjangkau. Sejumlah studi menunjukkan bahwa obat tradisional berpotensi sebagai agen penyembuh luka di samping pengobatan medis untuk luka bakar (Lin et al., 2010).

Saat ini penggunaan obat tradisional banyak dipilih oleh masyarakat karena memiliki beberapa keuntungan di antaranya penggunaanya yang mudah, harga yang relatif murah, memiliki

\footnotetext{
•email korespondensi: suhaeni.enny96@gmail.com
} 
efek samping yang lebih kecil dan bahan baku yang mudah diperoleh di lingkungan sekitarnya. Salah satu tumbuhan yang digunakan sebagai obat tradisional yaitu pepolo (Bischofia javanica Blume). Menurut Rajbongsih (2014), daun pepolo dapat digunakan untuk mengobati berbagai penyakit seperti kanker, diare, batuk, sakit tenggorokan dan luka bakar.

Menurut Prasad devi (2013), berdasarkan pengalaman masyarakat daun pepolo dapat mengatasi berbagai masalah kulit seperti luka bakar, dengan cara daun pepolo digiling sampai halus dan diaplikasikan pada kulit yang terkena luka bakar. Dari skrining fitokimia yang dilakukan Lingadurai (2011), daun pepolo mengandung senyawa alkaloid, sterol, triterpenoid, karbohidrat, protein, flavanoid, tannin, dan saponin. Beberapa penelitian juga telah dilakukan dan melaporkan adanya aktivitas dari daun pepolo sebagai antileukemia, antitusif, dan antinematoda (Rajbongsih, 2014). Sampai saat ini belum ada penelitian tentang aktivitas daun pepolo (Bischofia javanica Blume) terhadap penyembuhan luka bakar.

\section{BAHAN DAN METODE}

\section{Bahan}

Bahan-bahan yang digunakan dalam penelitian ini yaitu ekstrak etanol daun pepolo (Bschofia javanica Blume), akuades, etanol 96\%, Na CMC, gliserin, propilenglikol, ketamin dan gel bioplasenton, pakan.

\section{Ekstraksi Sampel}

Pembuatan ekstrak daun pepolo (Bischofia javanica Blume) dilakukan dengan cara diekstraksi dengan metode maserasi menggunakan pelarut etanol $96 \%$. Simplisia ini dimasukkan ke dalam bejana maserasi dan direndam dengan pelarut etanol $96 \%$ selama 3x24 jam dan diaduk setiap 1x24 jam selama 15 menit. Setelah dimaserasi selama 3 hari, kemudian disaring menggunakan saringan untuk mendapatkan filtratnya. Filtrat tersebut kemudian diuapkan menggunakan alat vacum rotary evaporator sehingga didapatkan ekstrak kental daun pepolo.

\section{Pembuatan Basis Gel}

Pembuatan basis gel dengan menggunakan sodium karboksimetil selulosa (Na-CMC) dilakukan sesuai prosedur pembuatan standar gel yang dilakukan oleh Hamzah (2006) dapat dilihat pada tabel berikut:
Tabel 1. Formula standar gel dengan basis Sodium Karboksimetil selulosa (Na-CMC)

\begin{tabular}{ccc}
\hline No & Bahan & Komposisi $(\% \mathbf{b} / \mathbf{b})$ \\
\hline 1 & Na-CMC & $5 \%$ \\
\hline 2 & Gliserin & $10 \%$ \\
\hline 3 & Propilenglikol & $5 \%$ \\
\hline 4 & Aquades ad & 100 \\
\hline
\end{tabular}

Pembuatan basis gel dilakukan dengan cara sebanyak $5 \mathrm{~g}$ Na-CMC dicampur dengan $10 \mathrm{~g}$ gliserin, $5 \mathrm{~g}$ propilenglikol dan dicukupkan $100 \mathrm{~g}$ dengan aquades lalu dipanaskan pada suhu $50^{\circ} \mathrm{C}$ dan diaduk hingga homogen. Pembuatan basis gel ini berfungsi sebagai media pembawa untuk ekstrak etanol daun pepolo. Basis gel yang akan dibuat dalam penelitian ini memiliki konsentrasi ekstrak daun pepolo yang berbeda-beda, yaitu 5\%, $10 \%$ dan $15 \%$ sebanyak $25 \mathrm{~g}$.

Tabel 2. Formulasi gel ekstrak daun pepolo

\begin{tabular}{ccccc}
\hline \multirow{2}{*}{ No } & \multirow{2}{*}{ Bahan } & \multicolumn{3}{c}{ Komposisi (g) } \\
\cline { 3 - 5 } 1 & $\begin{array}{c}\text { Ekstrak daun } \\
\text { pepolo }\end{array}$ & 1,25 & 2,5 & 3,75 \\
\hline 2 & Na-CMC & 1,25 & 1,25 & 1,25 \\
\hline 3 & Gliserin & 2,5 & 2,5 & 2,5 \\
\hline 4 & Propilenglikol & 1,25 & 1,25 & 1,25 \\
\hline 5 & Aquades ad & 25 & 25 & 25 \\
\hline
\end{tabular}

\section{Pengujian Efektivitas Terhadap Luka Bakar}

Hewan coba yang digunakan adalah kelinci (Oryctolagus cuniculus) yang sehat, dengan berat tubuh kelinci 1,5-2,0 kg pada umur 4-10 bulan, diaklimatisasi selama \pm 7 hari. Bulu kelinci dicukur pada bagian punggungnya, sebelum diinduksi panas kelinci dianastesi total terlebih dahulu dengan ketamin 1-2 mg/kg BB secara intravena telinga kelinci. Kemudian dilanjutkan dengan induksi kulit dengan logam panas berupa solder yang telah dimodifikasi dengan diameter sekitar $20 \mathrm{~mm}$ pada suhu $60^{\circ} \mathrm{C}$ selama 10 detik. Luka yang terjadi diukur, kemudian diberi perlakuan sesuai kelompoknya:

Kelompok 1: Kelompok kontrol positif, luka bakar dioleskan Bioplacenton

Kelompok 2: Kelompok kontrol negatif, luka bakar dioleskan basis gel tanpa ekstrak

Kelompok 3: Luka bakar dioleskan basis gel yang mengandung ekstrak daun pepolo $5 \%$ 
Kelompok 4: Luka bakar dioleskan basis gel yang mengandung ekstrak daun pepolo $10 \%$

Kelompok 5: Luka bakar dioleskan basis gel yang mengandung ekstrak daun pepolo $15 \%$

\section{Variabel Analisis Data}

Pengukuran rata-rata diameter luka bakar dilakukan dengan menggunakan rumus :

$$
d x=\frac{\mathrm{d} 1+\mathrm{d} 2+\mathrm{d} 3+\mathrm{d} 4}{4}
$$

\section{Keterangan:}

$\mathrm{dx}$ (diameter luka hari ke $\mathrm{x}$ ), d1 (diameter 1), d2 (diameter 2), d3 (diameter 3), d4 (diameter 4).

Dihitung persentase penyembuhan dengan rumus: $P \%=\frac{d 0-d x}{d o} \times 100 \%$

Keterangan:

$\mathrm{P} \%$ untuk persentase penyembuhan luka, $\mathrm{d}_{0}$ untuk diameter luka awal, $\mathrm{d}_{\mathrm{x}}$ untuk diameter luka pada hari tertentu. Kemudian dilakukan analisis data secara statistik menggunakan metode One Way ANOVA.

\section{HASIL}

\section{Ekstraksi Sampel}

Hasil proses maserasi simplisia daun pepolo dengan bobot $602,80 \mathrm{~g}$ menggunakan pelarut etanol 96\%, diperoleh hasil ekstrak kental sebanyak 39,22 dengan hasil rendemen sebesar $6,59 \%$.

\section{Uji Organoleptik Gel Ekstrak Daun Pepolo}

Tabel 3. Hasil Uji Organoleptik Hari ke-1

\begin{tabular}{|c|c|c|c|}
\hline $\begin{array}{c}\text { Pengamata } \\
\mathbf{n} \\
\end{array}$ & $\begin{array}{c}\text { Basis gel } \\
\text { dengan dosis } \\
\text { ekstrak } 5 \%\end{array}$ & $\begin{array}{c}\text { Basis gel } \\
\text { dengan dosis } \\
\text { ekstrak } 10 \%\end{array}$ & $\begin{array}{c}\text { Basis gel } \\
\text { dengan dosis } \\
\text { ekstrak } 15 \%\end{array}$ \\
\hline Bau & Bau khas & Bau khas & Bau khas \\
\hline Warna & $\begin{array}{l}\text { Hitam } \\
\text { kehijauan } \\
\text { agak } \\
\text { bening }\end{array}$ & $\begin{array}{c}\text { Hitam } \\
\text { kehijauan }\end{array}$ & $\begin{array}{l}\text { Hitam } \\
\text { kehijauan } \\
\text { pekat }\end{array}$ \\
\hline Tekstur & Kental & Kental & Kental \\
\hline
\end{tabular}

\section{Pengujian Pengaruh Pemberian Topikal Ekstrak Daun Pepolo Terhadap Diameter Luka Bakar}

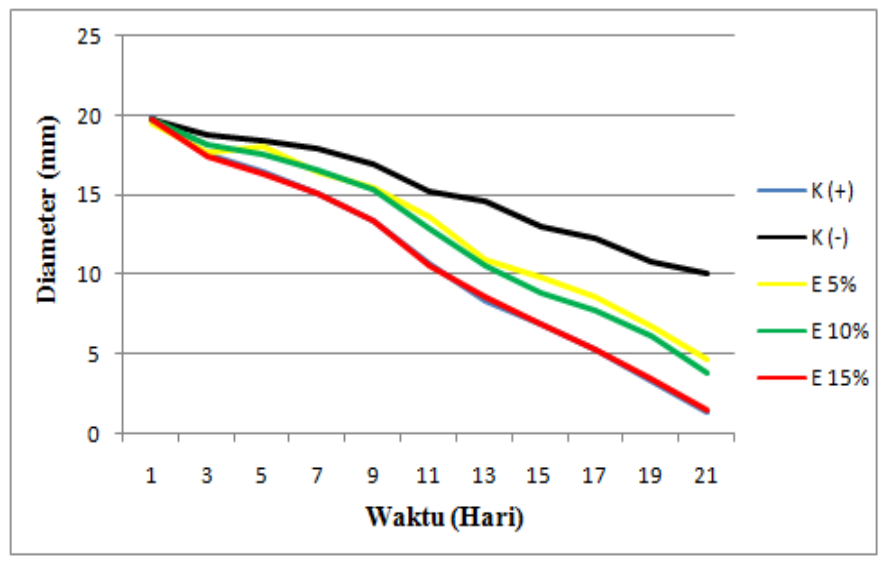

Gambar 1. Grafik hubungan antara diameter luka bakar vs hari

Keterangan:

$\mathrm{K}(+) \quad=$ Kontrol Positif (Bioplacenton)

$\mathrm{K}(-)=$ Kontrol Negatif (Basis gel tanpa ekstrak)

E 5\% = Ekstrak daun pepolo konsentrasi 5\%

$\mathrm{E} 10 \%=$ Ekstrak daun pepolo konsentrasi $10 \%$

E $15 \%=$ Ekstrak daun pepolo konsentrasi $15 \%$

\section{PEMBAHASAN}

Luka bakar diinduksi pada bagian punggung kelinci yang sebelumnya telah dicukur sebanyak 5 bagian luka bakar yang mewakili 5 kelompok perlakuan pada tiap ekor kelinci dengan menggunakan solder berupa logam panas yang telah dimodifikasi, dimana luka yang terbentuk berupa lingkaran dengan diameter sekitar $20 \mathrm{~mm}$. Sebelum diinduksi luka bakar, kelinci dianastesi terlebih dahulu menggunakan injeksi ketamin secara intravena.

Induksi luka bakar yang telah dilakukan mengakibatkan terjadinya kerusakan pada bagian epidermis dan sebagian dermis dengan ciri kulit mengalami pelepuhan, kulit kering dan dasar luka berwarna merah pucat. Dari hasil pengamatan luka bakar tersebut dapat dikatakan bahwa hewan uji mengalami luka bakar derajat II (Moenadjat, 2009).

Masing-masing luka bakar diberi perlakuan dengan basis gel tanpa esktrak sebagai kontrol negatif, konsentrasi ekstrak 5\%, 10\%, $15 \%$ dan gel Bioplacenton sebagai kontrol positif. Pemberian perlakuan dilakukan selama 21 hari dengan interval pengolesan 1 kali sehari $200 \mathrm{mg}$.

Analisis data dilakukan dengan menggunakan metode One Way Anova untuk mengetahui ada tidaknya perbedaan yang 
signifikan antar kelompok. Hasil analisis minggu ke-1, minggu ke-2 dan minggu ke-3 menunjukkan adanya perbedaan antar kelompok dengan nilai yang signifikan $(\mathrm{p}<0,05)$. Untuk mengetahui kelompok yang memiliki efek penyembuhan luka bakar yang berbeda secara signifikan maka analisis dilanjutkan dengan uji Post Hoc Duncan.

Hasil uji Post Hoc Duncan (Lampiran 8) minggu ke-1, minggu ke-2 dan minggu ke-3 menunjukkan efek penyembuhan luka bakar kontrol negatif berbeda signifikan dengan perlakuan ekstrak daun pepolo 5\% dan $10 \%$, konsentrasi ekstrak 5\% dan $10 \%$ memiliki perbedaan yang tidak signifikan, namun berbeda signifikan dengan konsentrasi ekstrak $15 \%$ dan kontrol positif, antara konsentrasi ekstrak $15 \%$ dan kontrol positif memiliki perbedaan yang tidak signifikan. Namun kontrol positif memiliki efektivitas penyembuhan luka bakar yang lebih baik dibandingkan dengan ekstrak daun pepolo $15 \%$.

Ekstrak daun pepolo 5\% memberikan efek, tapi tidak sebanding dengan ekstrak daun pepolo $10 \%$. Sedangkan ekstrak daun pepolo $15 \%$ memiliki efek yang sebanding hal ini diduga karena konsentrasi tersebut adalah konsentrasi yang efektif dalam proses penyembuhan luka bakar dan mampu memberikan tingkat kejenuhan pada kulit sehingga makin tingginya konsentrasi tidak akan mempengaruhi kemampuan penetrasinya dan respon atau efekpun tidak akan bertambah.

\section{KESIMPULAN}

Berdasarkan penelitian yang telah dilakukan, mengenai pengujian efektivitas ekstrak etanol daun pepolo (Bischofia javanica Blume) terhadap penyembuhan luka bakar pada kelinci (Oryctolagus cuniculus) jantan, dapat disimpulkan sebagai berikut: Ekstrak daun pepolo (Bischofia javanica Blume) memiliki aktivitas terhadap penyembuhan luka bakar pada punggung kelinci (Oryctolagus cuniculus), ekstrak daun pepolo (Bischofia javanica Blume) dengan konsentrasi $15 \%$ efektif terhadap penyembuhan luka bakar pada punggung kelinci (Oryctolagus cuniculus).

\section{SARAN}

Perlu dilakukan penelitian lebih lanjut untuk mengetahui apakah ekstrak daun pepolo memeiliki efek penyembuhan sebagai antibakteri pada luka yang terinfeksi.

\section{DAFTAR PUSTAKA}

Ekrami, A and Kalantar, E. 2007. Bacterial Infections in Burn Patients at A Burn Hospital in Iran. Indian Journal Medical Research. 126:541-544.

Gupta VK, Pathak SS, Jain MK. Evaluation of burn wound healing property of Ocimum sanctum by monitoring of period of reepithelization in rabbits. Int. $J$ Basic Clin Pharmacol. 2016; 5:146-148.

Hamzah, M. Mazwadehet al. 2006. AntiInflammatory Activity ofAchillea and Ruscus Topical Gel on CarrageenanInduced Paw Edema in Rats. Acta Poloniae Pharmaceutica - Drug Research. 63(4): 277-280.

Khorasani, G., S.J. Hosseinimehr, M. Azadbakht, A. Zamani and M.R. Mahdavi, (2009). Aloe versus silver sulfadiazine creams for second-81 degree burns: a randomized controlled study. Surg. Today, 39: 587-591.

Lin, T.S., Azian, A.L., Srijit, D., 2010. Use of Traditional Herbal. Journal of Clinical Dermatology, pp.1-5.Majid, A., Prayogi, A.S., 2013. Perawatan Pasien Luka Bakar. Yogyakarta: Gosyen Publishing.

Lingadurai S, Roy S, Joseph RV, Nath LK. Antileukemic activity of the leaf extract of Bischofia javanica blume on human leukemic celllines. Indian $\mathrm{J}$ Pharmacol 2011;43:143-149

Moenadjat, Yefta. 2009. Luka Bakar dan Tatalaksana Edisi ke 4. Jakarta: FKUI.

Peck Michael, Joseph Molnar \& Dehran Swart. 2009. Bulletin of the World Healt Organization A global plan for burn prevention and care. $<$ http://who.int/bulletin/volu

Prasad Devi AG, Shyma TB, Medicinal plants used by the tribes of Vythiritaluk, Wayanad district (Kerala state) for the treatment of human and domestic animal ailments, Journal of Medicinal Plants Research, 7, 2013, 1439-1451

Rajbongshi, P.P., Kamaruz, Z, Sangeeta, B., dan Simanti, D. (2014). A Review on Traditional Use and Phytopharmacological 
Potential of Bischofia Javanica Blume. International Journal of Pharmaceutical Sciences Review and Research.
Departemen Kesehatan Republik Indonesia. Laporan Hasil Riset Kesehatan Dasar Indonesia (Riskesdas). 2013 